Please do not destroy or throw away this publication. If you have wo furtity for it write to the Geological Survey at Washington and ask for a fonik toretwon If

DIRPARTMENT OF THE INTTKROOA

Doy 0. West, Secretary

U. S. GEOLOGICAL SURVEY

George Otis-Smith, Director

Professional Paper 154-E

\title{
OIL SHALE IN A PRODUCING OIL FIELD IN CALIFORNIA
}

BY

H. W. HOOTS

Published March 20, 1929

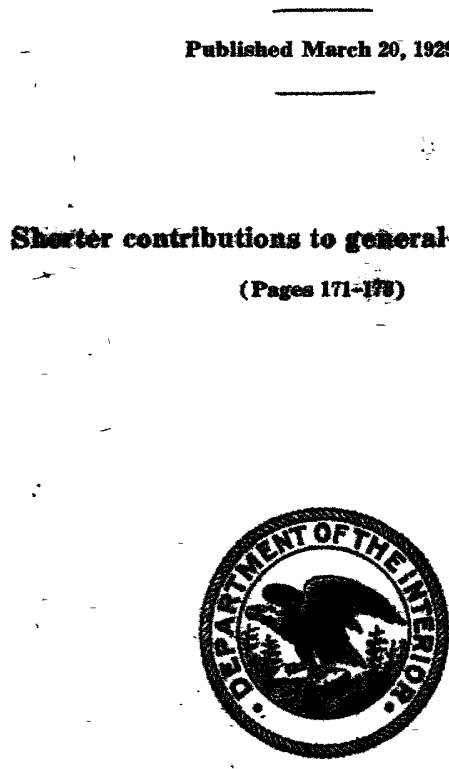

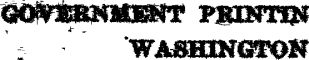

1928 


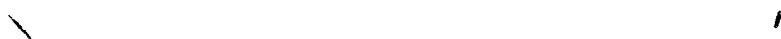

\section{CONTENTS}

General features...

Microscopic character and richness

Age of the oil shale.

Stratigraphic relation of oil shale to oil-producing zone

Significance of the stratigraphic relation.

\section{ILLUSTRATION}

Plate 17. $A$, Photomicrograph of a thin section of oil shale from Wheeler Ridge, Calif.; $B$, north-south section across axial part of Wheeler Ridge anticline, Calif., showing stratigraphic relation of oil shale to beds producing oil.- 


\title{
OIL SHALE IN A PRODUCING OIL FIELD IN CALIFORNIA
}

\author{
By H. W. Ноoтs
}

General features.-A considerable thickness of oil shale has been penetrated by a well drilled in the southwest corner of sec. 22 , T. 11 N., R. 20 W., on the north flank of Wheeler Ridge, at the south end of San Joaquin Valley, Calif. This shale is similar to oil shale found in some of our Rocky Mountain States in that it contains no free oil but includes much detrital carbonaceous material, which when heated yields oil. Nearly continuous cores of this shale and associated fine sandstone and sandy shale were taken from depths of 1,869 to 4,090 feet, a range that represents a stratigraphic thickness of about 1,400 feet. The cores were 4 inches in diameter. In 1924, just before the well was abandoned, the writer was permitted by officials of the Midland Oilfields Co. (Ltd.), of Fellows, Calif., to sample these cores for later examination.

Shale in some of the samples taken is dark brownish gray to black, has the appearance of hard rubber, and is finely laminated throughout. Dark carbonaceous laminae alternate with others of light buff-gray color, which are commonly calcareous. Small calcareous nodules from one-eighth to one-half inch in diameter are abundant in some of the samples. In other samples, not so rich in hydrocarbons, shale either alternates with laminae and thin beds of fine gray sand or is splotched irregularly with $1 / 4$-inch to $1 / 2$-inch patches of sand not so fine in texture.

The dense brown rubberlike appearance of some of the shale suggested its bituminous character. Upon heating small crushed samples in test tubes it was found that different quantities of dark-brown oil were driven off, and that some samples, it was estimated, yielded as much as 25 per cent by volume of volatile hydrocarbons that condensed to oil. None of the samples, when crushed and subjected to the solvent action of carbon tetrachloride, ether, or chloroform, were found to contain free oil. Miss Taisia Stadnichenko, of the National Research Council, made additional tests with various solvents and obtained the same results. These tests, however, were applied to - only about a dozen small samples taken from the 1,400 feet of shale penetrated by the well, and they do not prove that free oil is not associated with bituminous material in much of the shale. Free oil and oil residues are known to be associated with bituminous shale in other parts of California.

Microscopic character and richness.-An accurate statement of the character and richness of the entire $100368^{\circ}-29$ rock thickness penetrated by this well can not be given. Cores were taken from only part of the well. At the time of sampling the presence of oil shale was not suspected, and the 82 collected samples, an average of one sample for every 27 feet of depth, may not contain representatives of the best oil shale penetrated by the drill.

Thin sections were made from some of the samples that appeared richest and were submitted to David White for examination. His statements concernino the character and content of these shales apper. below.

.The carbonaceous shales found at different depths in the well have been examined by means of thin sections cut both vertical and parallel to the bedding. All these sections show much owganie matter, including a rather large amount of débris that consists largely of the outer coats of algae, which were more or less cutinized or fatty, together with a few spores of different kinds and some miscellaneous débris. In general aspect, chara?ter, and arrangement of débris and "ulmic" colloidal matter $\varepsilon$.l the specimens belong to the normal laminated type of oil shal?, whether it be as old as the Devonian or as young as the Tertiar: In short, these shales are charactertistic bituminous or oil shales, in which, in general, only the somewhat decay-resistant organic structures are preserved.

Estimation from the thin sections of the possible yield of tl shale is difficult, but I am inclined to hazard the forecast that shale like the thin layers from which some of the sections weer cut would probably yield as much as 30 gallons of distillate to the ton of rock.

In addition to the algae, spores, and other organic remains noted by $\mathrm{Mr}$. White, some thin sections show distinct outlines of calcarsous Foraminifera, which, according to D. D. Hughes, ${ }^{1}$ belong to the gener? Bolivina, Bulimina, and Buliminella. Dr. Paul P. Goudkoff ${ }^{2}$ found these same forms to be common in comminuted samples of eores taken from depths below 3,040 feet. Higher in the well, between depths of 1,900 and 3,040 feet, Foraminifera contained in tha cores, according to Doctor Goudkaff, are entirely arenaceous forms. He found that remains of diatoms are either entirely absent or scarce in all samples examined. This statement applies equally well to tha thin sections.

'In hand specimens amber-colored fish scales wer"9 noted to be abundant throughout practically all trs cores. In one sample the crushed partial skeleton of a fish was preserved along the bedding plane of corpact, finely laminated dark-brown shale.

1 Oral communication

2 Letter dated Dec. 22, 1926. 
Of the available small samples having indications of at least moderately high content of carbonaceous material, those large enough for partial distillation tests were tested by the United States Bureau of Mines. Unfortunately, before the distillation tests were made the original small samples had been twice reduced in size for micropaleontologic studies, and as a result some of the best samples, including some of those examined by Mr. White and heated in test tubes by the writer were too small for distillation tests. Yields of oil from the tested samples are listed below.

Results of distillation tests on oil shale from Wheeler Ridge, Calif.

\begin{tabular}{|r|r|}
\hline Depth (feet) & $\begin{array}{c}\text { Oil yield } \\
\text { (gallons to } \\
\text { the ton) }\end{array}$ \\
\hline $2,646-2,651$ & 3.07 \\
3,040 & 2.04 \\
3,196 & 3.28 \\
$3,352-3,358$ & 4.73 \\
$3,491-3,496$ & 2.40 \\
$3,536-3,538$ & 9.27 \\
\hline
\end{tabular}

Specific gravity of oil from last sample, 0.9490. Not sufficient oil produced for complete distillation.

The accompanying photomicrograph (pl. 17, A) of one of the thin sections, cut normal to the bedding of a small sample taken from a depth between 3,475 and 3,480 feet, illustrates the microscopic character of some of the best samples examined. Dark portions of this photograph appear in the thin section as darkbrown lamellae of carbonaceous material, which are intercalated with irregular stringers of a pale-brown (nearly colorless) substance, some of which is isotropic with an index of refraction less than 1.54. This substance is syngenetic and appears to be silica in the form of opal and incipient chalcedony. Minute grains of quartz and feldspar are abundant, and the outline and inner structure of a foraminifer appear in the upper right quadrant of the picture. According to W. H. Bradley, of the United States Geological Survey, this and other slides appear to compare favorably in content of carbonaceous material to fairly good oil shales from the Green River formation of the Rocky Mountain region. The previously mentioned estimate, based on heating of test-tube portions, that some samples yield as much as 25 per cent by volume of volatile hydrocarbons that condense to form oil (about 30 gallons to the ton of rock) may be considered an approximation to the potential oil content of the best samples.

Age of the oil shale.-The Midland well was drilled on the outcrop of rocks considered as belonging to the Pliocene Etchegoin formation. The arenaceous Foraminifera found in the upper 1,000 feet of the cores, between depths of 2,000 and 3,040 feet; are reported by Doctor Goudkoff to be the same as those found in strata mapped by Arnold and Anderson ${ }^{3}$ as

arnold, Ralph, and Anderson, Robert, Geology and oil resurces of the Coalinga district, Calif.: U. S. Geol. Survey Bull. 398, PI. I, 1910. the Santa Margarita formation (upper Miocene) of the Pyramid Hills and Big Tar Canyon, in the Coalinga district. The calcareous Foraminifera found below 3,040 feet in depth are considered by Dortor Goudkoff to belong to the Maricopa shale (upper and middle Miocene). It is fairly certain that most, if not all, of the oil shale at Wheeler Ridge is of Micsene age.

Stratigraphic relation of oil shale to oil-producing zone.-Many shows of oil and of oil and gas were obtained in the Midland well, and they were all cenfined to that portion of the well in which oil shale is common. (See pl. 17, B.) This striking relation may be due in part to the fact that the Miocene "brown shale" strata, in which oil shale oecurs are the only beds that were cored and examined carefully for oil content. Nevertheless it is noteworthy that a column of rock containing considerable oil shale also yields strong shows of petroleum. This relation is substantiated and becomes even more striking when it is noted, as shown in Plate $17, B$, that this same stratigraphic interval corresponds to most of the producing zone of the Wheeler Ridge oil field, only 1,100 feet south of the Midland well.

Significance of the stratigraphic relation.-Has the oil now being produced from porous strata in the Wheeler Ridge field been derived from the abunds.nt and varied detrital organic material of intercalated oil shale, or has it originated, according to the mc "e commonly accepted theory for California oil, in deener and possibly also more distant shale deposits, which may be composed largely of diatoms and their rmains? The available evidence provides no answer to this question. According to experiments conducted by $\mathrm{McCoy}^{4}$ and Trager, ${ }^{5}$ oil shale when subjected to pressure will yield free oil; but even though this fact and the close stratigraphic relation between oil shale nnd petroleum production in Wheeler Ridge are certainly suggestive, the possibility must be considered that this relation is entirely accidental and that the Whenler Ridge oil has been derived from another source. On the assumption that oil shale will yield petroleum under natural conditions resulting from deep burial and pronounced deformation, it must be conceded that there is field evidence at Wheeler Ridge that supports a plausible theory for the origin of oil at this locality-a theory that is ideal in simplicity and th at avoids the difficulties encountered by assuming migration of oil generated in deeper or more distant streta. Diatoms and Foraminifera associated with the oil shale may also have contributed oil to intercalated petroliferous. beds, but from their apparent scarcity in the oilproducing strata of this area it appears probable that they are of minor importance as source material.

Is typical oil shale, such as this at Wheeler Ridge, more common in fields that are producing oil than is

4 McCoy, A. W., Notes on the principles of oil accumulition: Jour. Cleology, vol. 27, pp. 252-262, 1919.

5 Trager, E. A., Kerogen and its relation to the origin of oil: Am. Assec. Petroleum Geologists Bull., vol. 8, pp. 301-311, 1924. 


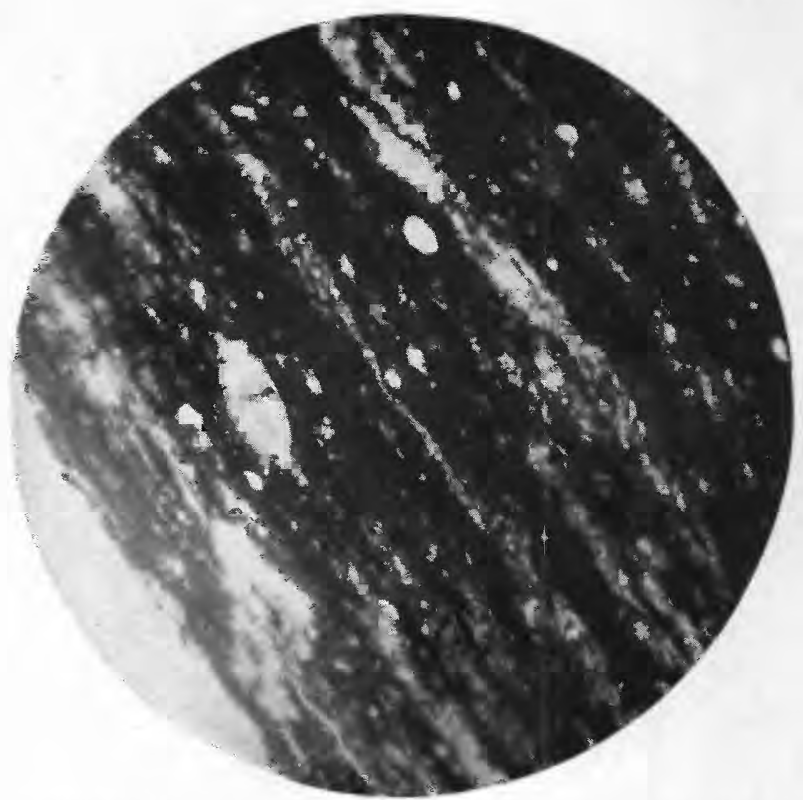

A. PHOTOMICROGRAPH OF A THIN SECTIUN OF OIL SHALE FROM WHEELER RIDGE, CALIFORNIA

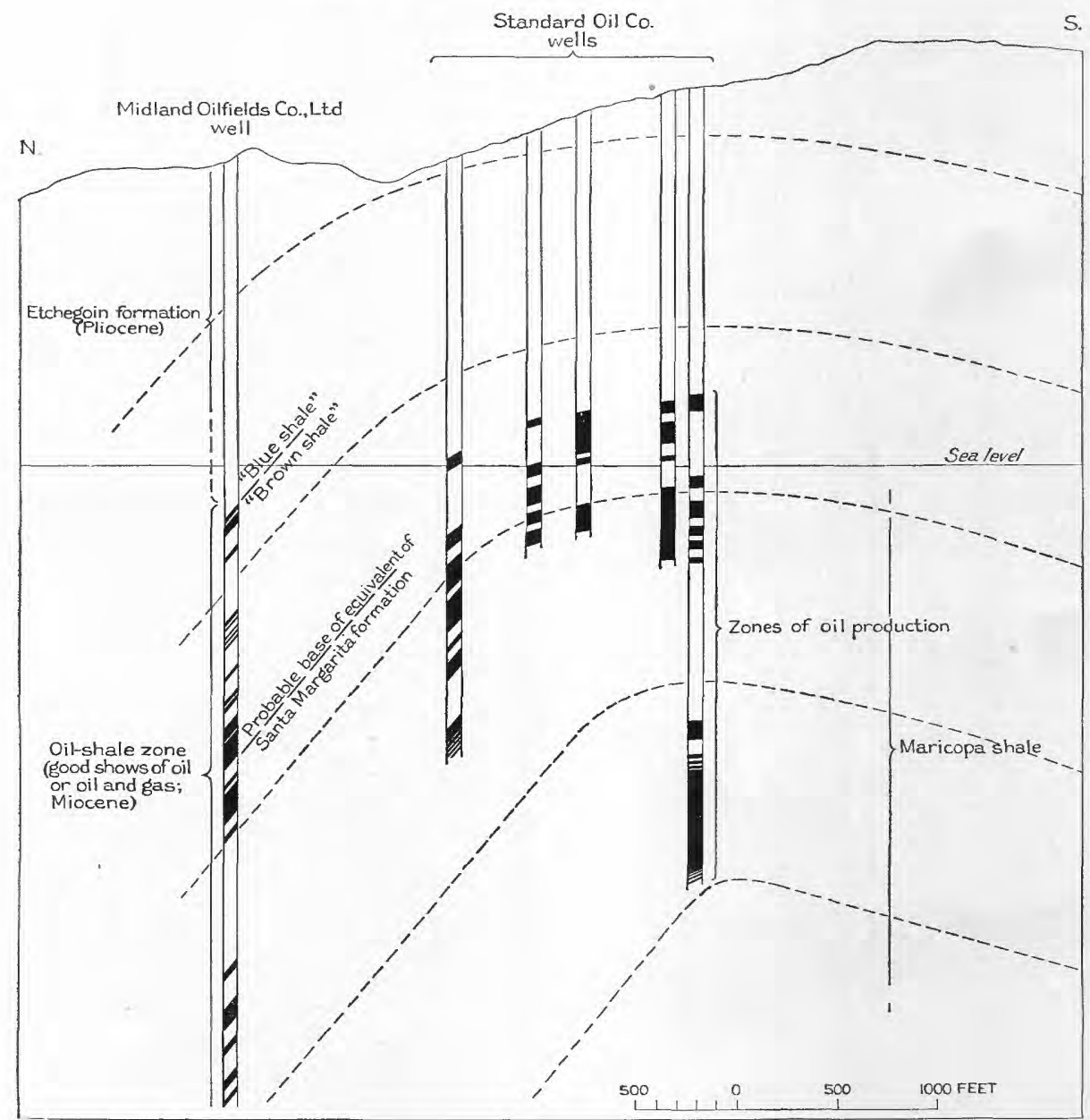

B. NORTH-SOUTH SECTION ACROSS AXIAL PART OF WHEELER RIDGE ANTICLINE CALIFORNIA, SHOWING STRATIGRAPHIC RELATION OF OIL SHALE TO BEDS PRODUCING OIL 


\section{-}


now generally recognized? Such oil shale may be of common occurrence in Pliocene as well as Miocene oil-yielding strata of California.

It will be noted from the photomicrograph (pl. 17, A) that unmistakable marine Foraminifera occur embedded within the fine laminations of rich carbonaceous material. These fragile forms are unbroken and show no evidence of having been reworked; they appear to prove that the oil shale is of marine origin. In this way the Wheeler Ridge shale is similar to the Devonian oil shales of Kentucky and Indiana but differs from the extensive Eocene deposits of oil shale in the Rocky Mountain region, which, according to Bradley, ${ }^{6}$ were

G Bradley, W. H., Shore phases of the Green River formation in northern sweetwater County, Wyo.: U. S. Geol. Survey Prof. Paper 140, pp. 127-128, 1926. formed from organic sediments deposited in large inland lakes.

It would appear that if typical oil shale will yield petroleum under natural conditions which have prevailed since its deposition, any stratigraphic zone of oil shale or other highly organic rock, whether of merine or lacustrine origin and even though entirely devoid of recognizablefossils, should be considered an adequate source for petroleum deposits in areas where overburden has been great or, where deformation has been intense. At Wheeler Ridge the oil-shale beds, toge ther with about 4,000 feet of overlying Pliocene sedimonts, have been folded into an asymmetric anticline whose limbs dip $20^{\circ}$ and $50^{\circ}$. 
